\title{
Os sinos da agonia: um banquete barroquizante a ser degustado aqui e agora
}

\author{
Maria José Oliveira Araújo Guerra*
}

\begin{abstract}
Resumo
Neste artigo, nosso intuito é mostrar como Autran Dourado, em Os sinos da agonia, recorre ao barroco como estilo de escrita, estilo que apela para a experiência humana, imbricada no jogo metafórico, num verdadeiro desdobramento de imagens, em um movimento que dá forma ao caótico mundo humano. Em nossa leitura, esse movimento de apropriação encena a recursividade da mente humana, mente antropofágica por excelência, em processo de (re)criação contínua e ininterrupta.

Palavras-chave: Barroco. Recursividade. Antropofagia. Mente literária.
\end{abstract}

* Pontifícia Universidade Católica de Minas Gerais. Doutoranda em Literaturas de Língua Portuguesa pela PUC Minas. Professora na rede municipal de Belo Horizonte. ORCID: https://orcid.org/my-orcid?orcid=0000-0003-3029-4073. 


\title{
The bells of agony: a baroque feast to be enjoyed here and now
}

\begin{abstract}
In this article, our intention is to show how Autran Dourado, in Os Sinos Da Agonia (Bells of Agony), resorts on the baroque as a writing style, a style that appeals to the human experience, imbricated in the metaphorical game in a true unfolding of images, in a movement that gives shape to the chaotic human world. In our interpretation, this appropriation movement stages the recursion of the human mind, par excellence an anthropophagic mind, in a process of a continuous and uninterrupted (re)creation process.
\end{abstract}

Keywords: Baroque. Recursivity. Anthropophagy. Literary mind.

Recebido em: 06/09/2021 // Aceito em: 27/11/2021. 
O escritor não é um nem observador nem um sonhador. A literatura não reflete a vida, mas também não escapa ou se retira dela: engole-a. E a imaginação não para enquanto não engolir tudo. Qualquer que seja o ponto de que partimos e o rumo que tomamos, a sinalização da literatura continua a apontar para a mesma direção: para um mundo onde nada existe fora da imaginação humana. (Northrop Frye, 2017, p. 70).

Parece estar no cerne do Barroco algo da constituição do homem, de seu ser e estar no mundo contemporâneo. Ou seria o contrário? O Barroco é nosso espírito; o espírito barroco se faz estilo. Encontramos ecos na música popular, na moda, nas artes plásticas, na arquitetura, na indústria cultural, na literatura. Pensando no movimento artístico, mais especificamente no campo literário, ele supera os limites de tempo e espaço, tornando-se algo da ordem do universal, em que o sujeito tem consciência de seu estatuto de desamparo visceral. Volta e meia é (re)visitado, (re)lido, ressignificado, potencializando leituras de nosso mundo fragmentado, em que a razão, que se queria luz natural do homem, mostra-se precária. Ser barroco e moderno, assim, não é paradoxal, mas, sim, convergente. Convergência essa que implica diferença, pois cada escritor/poeta e/ou leitor, ao fazer sua releitura, numa renovação da tradição, a faz de modo subjetivo, mas também plural, colocando em pauta diálogos entre culturas, literaturas e autores. Neste breve texto, trazemos cenas da obra Os sinos da agonia, ${ }^{1}$ em que Autran Dourado promove o diálogo com o barroco, não fazendo uma simples incorporação de elementos da estética em si, mas retomando-os de forma renovada, o que, paradoxalmente, concede profunda modernidade à narrativa.

1 Algumas reflexões aqui apresentadas foram aprofundadas em Guerra (2019). 
De que Barroco se fala? Não se trata do movimento histórico artístico que teve início no século XVII e se estendeu até meados do século XVIII, em um momento bastante conturbado, apesar de suas características serem relevantes para o diálogo na contemporaneidade. Do período pretérito, guardamos manifestações que mostram, em diferentes tons e nuances, o homem buscando conciliar os valores materiais, o antropocentrismo, o predomínio da razão sobre os sentimentos, amplamente pregados pelo Renascimento, com os valores espirituais, a visão teocêntrica do mundo, o afeto emocional, típicos das tradições medievais. Em meio a conflitos de ordem política, econômica, social e, principalmente, religiosa, saltam aos olhos o apego às curvas, aos movimentos, ao drama, à decoração ostensiva e, de forma paradoxal, à sensualidade. $\mathrm{O}$ exagero de detalhes, o contraste entre o claro e o escuro, os raciocínios complexos, vieram de encontro à clareza de ideias e ao raciocínio dito lógico e linear. Se atentarmos para a etimologia da palavra, encontraremos algumas variações, mas todas aproximadas semanticamente. ${ }^{2} \mathrm{O}$ nome "barroco" designava algo imperfeito, extravagante, que fugia da ordem e do equilíbrio das formas da arte clássica.

O caráter pejorativo só ganharia um novo olhar no final do século XIX, com contraposições tecidas em relação à estética renascentista (WÖLFFLIN, 1984): linear versus pictórico, plano versus profundo, forma fechada versus forma aberta, unidade versus multiplicidade. Esses conceitos tiveram outros desdobramentos como estático versus dinâmico, simétrico versus assimétrico, precisão versus imprecisão, e assim por

\footnotetext{
2 Do francês boroque, significaria "irregular"; do grego, barros, apontaria para "algo pesado"; já a origem italiana barocchio, estaria para "engano", "fraude"; já em português, a palavra teria aparecido a partir da versão em espanhol berrueca, evolução do latim verruca, que significa "verruga"; ou ainda uma pedra irregular granítica ou uma pérola de forma irregular. Para saber mais, acesse: < https://www.dicionarioetimologico.com.br/barroco/>.
} 
diante. É possível afirmar que o barroco desequilibra qualquer estabilidade, fazendo entrechocar as leis clássicas e bem definidas, ou seja, sua força de mudança contínua reside na falta de contornos e na impressão de movimento.

Essas características, amplamente percebidas e estudadas nas artes plásticas, se estendem à literatura (HATZFELD, 2002), com destaque para a tendência à fusão, que se daria estrutural e estilisticamente, na criação de uma sinfonia literária entre elementos considerados díspares, com a encenação da consciência das personagens e a multiplicidade de pontos de vista, em que se esvai a ideia de verdade única.

Multiplicidade, dinamicidade, jogo de claro-escuro, quebra de linearidade, descontinuidade, paradoxos, desassossego, assimetria: modo de ver o mundo, modo barroco de concepção de mundo. Um mundo caótico que nos leva a Walter Benjamin no célebre Origem do drama barroco alemão (1984), cujas reflexões são retomadas em trabalhos interpretativos tanto sobre o Barroco histórico, quanto sobre manifestações barrocas de seu tempo. Para o momento, interessa-nos as considerações do ensaísta sobre a clara distinção entre a noção de símbolo e de alegoria. O símbolo estaria ligado ao domínio da teologia, à manifestação da essência divina na natureza, à unidade absoluta e perpétua, em uma fusão do belo com o divino que concorreria para a "imanência absoluta do mundo da ética no mundo do belo [...]" (BENJAMIN, 1984, p. 182), intensamente usado no Classicismo. Já a alegoria nasce da combinação entre natureza e história e, como tal, se caracteriza pela fragmentação, de forma que, em vez de permanência, traz a inscrição da transitoriedade em sua arte. Escrita por imagens, utilizando fragmentos desordenados, a alegoria mostra uma outra "verdade". A 
alegoria, em oposição ao símbolo, opera uma tensão entre contrários, sendo uma maneira de pensar a história a partir de uma visão de mundo em sua ruína. Assim como a escrita barroca, a alegoria não daria ideia de completude, ao contrário, ela seria despedaçada, dialética, aberta a significações. Diz o autor: "Em contraste, a apoteose barroca é dialética. Ela se consuma no movimento entre os extremos [...]" (BENJAMIN, 1984, p. 182).

Encontramos ideias consoantes às de Benjamin nos estudos de Walter Moser (1994) ao explicitar o movimento Barroco nos dias atuais, partindo das características atribuídas a sua fase histórica, que passou por uma certa "inversão ideológica", pois ocupava uma posição reacionária, ligada à contrarreforma, aos ideais de totalização política, ao controle da liberdade e da razão. O Barroco histórico acabou sendo uma estética de que se apropriaram instituições e/ou poderes contrapostos aos ideais da Modernidade, tais quais a Igreja, a monarquia e a aristocracia. Como tudo era pensado para gerar emoção, para atingir o espectador/leitor pela excitação dos sentidos, as obras revelavam-se em cenas dramáticas, capazes de fazer o observador se comover com o drama e a dor das personagens. Para o autor, esse intento de provocar no público a emoção seria uma certa "potência barroca" que, no entanto, não se concretizou totalmente na Modernidade por ir contra seus ideais de racionalidade. Nos dias atuais, a potencialidade barroca teria encontrado campo para se intensificar, já que novas tecnologias facilitariam, no sujeito-espectador, a excitação dos sentidos. Com novos recursos técnicos, a arte ganharia uma potência "intermidiática", pois a tecnologia possui como características mobilidade, multifuncionalidade, convergência e integração. A ressurgência do Barroco adquiriria propriedades da contemporaneidade, ou 
seja, seria um ressurgimento que dialogaria com as dinâmicas contemporâneas, de aspectos e valores distintos. Por isso mesmo, o autor utiliza o termo "barroquizante", um adjetivo que supõe certa transformação de artefatos culturais à disposição do artista. Em termos estéticos, o Barroco ressurgido se fundaria na relação com elementos de outras épocas e culturas, significando-os com base em um "aqui" e um "agora".

Vincenzo Russo (2009), comentando as ideias de Moser, assevera que essa apropriação de elementos para a manipulação estética pressupõe uma relação estilhaçada entre passado e presente. À maneira benjaminiana de se conceber a história, Moser também a vê como um processo não de uma, mas de várias histórias, negando-lhe o caráter de progressão linear, sempre dirigida para o progresso, para o futuro. As produções artísticas atuais, dentro dessa perspectiva, não estariam atreladas ao Barroco histórico, mas lançariam um olhar para o passado a partir do presente. E, se a origem do barroco é mesmo o século XVII, "quanto mais a memória dele se distancia e dele se esquece, tanto mais os materiais do passado barroco podem ser reciclados num contexto contemporâneo." (RUSSO, 2009, p. 73). Os materiais de outrora viram elementos de manipulação estética, sua reutilização empreendida numa nova criação, de modo que "[a] memória histórico-cultural, arrastada pelo esquecimento da tradição, pode apenas participar de uma memória despedaçada, que usa exclusivamente o que precisa, o que melhor se adapta à sua nova reelaboração artística.” (RUSSO, 2009, p. 73).

Em linha análoga, podemos retomar a ideia de "reciclagem estética" ou "reciclagem cultural" (MOSER, 2017), deslocamentos que se pautam, ao mesmo tempo, em repetição e diferença. Trata-se de trabalho criativo, sempre novo. Os 
materiais barrocos podem ser retomados, mas sofrem uma espécie de “des-historicização pós-moderna, cujo uso já não necessita ser legitimado pelo seu conteúdo histórico (a pertença ao barroco, por exemplo), mas apenas regulamentado por estruturas imanentes ao próprio contexto estético [...]" (RUSSO, 2009, p. 73). Estaríamos diante do "retorno do barroco" (MOSER, 1994), ocorrido por causa do interesse crescente pela estética, que passou a permear, de modo processual, o imaginário do século $\mathrm{XX}$, e teve seus traços atualizados na contemporaneidade. A aproximação aqui se mostra: o homem contemporâneo, assim como o homem barroco, encontra-se profundamente angustiado ao perceber a sua impotência diante do mundo estilhaçado. Nada mais é completo, panorâmico, definido. Esteticamente, tudo se mostra composto por ideias e imagens postos em textos que retomam textos, ou melhor, artefatos culturais que dialogam com artefatos outros, sem existir o "isto ou aquilo", e, sim, o "isto e aquilo".

No Brasil, vale marcar as postulações de Haroldo de Campos (2006) para quem a arte barroca teve um papel importante na desconstrução da tradição logocêntrica do Ocidente, que buscava uma só verdade universal. Ele usa o conceito de antropofagia para marcar o diálogo e a diferença na cultura brasileira, em um movimento relacional que inclui o outro. Sob esse prisma, considera Gregório de Matos o primeiro antropófago brasileiro, um verdadeiro tradutor e devorador da cultura de outrem. Compreende-se o barroco como traço distintivo de uma cultura híbrida, de que a alteridade seria a expressão. Campos rejeita a questão diacrônica e vê o barroco como uma força perturbadora da modernidade, que acaba por ressoar na contemporaneidade. $\mathrm{O}$ gesto antropofágico é encenado como manifestação da arte não 
estanque, mas, sim, ressignificada, no diálogo com a tradição.

Destaquemos, nas reflexões de Campos, essa figura do antropófago, que sempre esteve presente na cultura brasileira, ${ }^{3}$ como apropriador da alteridade, em um movimento incessante de retomadas de textos, de narrativas e de dados, em múltiplos contextos e variadas circunstâncias - mais contemporâneo, impossível. No mundo globalizado, é necessário lidar com a coexistência de informações, mídias, meios e linguagens. No mundo, não apenas no Brasil. Sem deixar de destacar a potência da antropofagia oswaldiana para a cultura brasileira, inclusive na academia, João Cézar de Castro Rocha (2011) propõe desassociarmos traços de autoria e de nacionalidade do conceito. Se no Manifesto de poesia pau-brasil, em 1924, Oswald de Andrade desenvolve um projeto estético artístico nacional que tem como base o primitivismo, no Manifesto antropófago, de 1928, o artista promove uma inversão do modelo de trocas culturais. No entanto, nessa inversão, numa clara assimilação e valorização do outro, não há ecos de brasilidade. Nas primeiras frases do manifesto - "Só a ANTROPOFAGIA nos une. Socialmente. Economicamente. Filosoficamente. Única lei do mundo. Expressão mascarada de todos os individualismos, de todos os coletivismos. De todas as religiões. De todos os tratados de paz." (ANDRADE, 1990, p. 47) -, vemos sinalizado seu caráter antropológico e, portanto, universal. Em geral, a antropofagia é vista como definição da identidade brasileira e, muitas vezes, numa chave exótica. O conceito sistematizado por Oswald em 1928, no entanto, permite lê-lo como algo da capacidade humana, processo (e não produto) de assimilação do que não nos pertence, mas que nos serve para viver, para criar.

3 Sobre as retomadas do conceito de antropofagia na cultura brasileira, ler Alves (2020). 
A apropriação ininterrupta e contínua se dá em contextos assimétricos, em apreensão de experiências diversas, simultaneamente, sem estabelecimento de hierarquias. E essa pode ser a nossa contribuição teórica para entender o mundo contemporâneo, globalizado, em que as fronteiras estão esfumadas pelo fluxo exacerbado de informações e por uma pluralidade de meios de comunicação, e em que a apropriação da contribuição do outro já não é mais imposta, mas, sim, volitiva, em diversos contextos, econômicos, políticos e/ou culturais (ROCHA, 2011).

No campo da literatura, a palavra "filiação", presente no manifesto de 1928, coloca em xeque a questão de originalidade, dando enfoque a horizontes comuns. A filiação é a felix culpa do poeta/escritor antropófago (ROCHA, 2011). Não há de se falar em "angústia da influência", sentimento por muito tempo sentido e estudado no campo das artes. Há produtividade, e muita, e criativa: valorização do criador, valorização de suas referências. Assim, talvez a melhor palavra a ser usada seja "confluências", em um verdadeiro embaralhamento de fronteiras, como encenado por Borges (1995) em Kafka e seus precursores e Pierre Menard, autor de Quixote. ${ }^{4}$ Se assim é, a criação, em alguma medida, é sempre marcada pelo vínculo orgânico com a tradição, mesmo que o gesto seja de confronto, de negação, perdendo todo o sentido a alcunha de antropófago direcionada apenas para os colonizados, pois devoradores de culturas somos todos e o processo de criação nunca é adâmico.

Como podemos perceber, Rocha (2011) potencializa Oswald de Andrade. A retomada também foi feita por Ivete

\footnotetext{
4 Em Pierre Menard, autor de Quixote, Borges potencializa o gesto de apropriação do alheio, em que as linhas idênticas às de Cervantes são outras, completamente novas. Já em Kafka e seus precursores, o autor inverte a produção textual, e o que é lido e colocado em cena pelo leitor altera os textos do passado. O modo de ler à disposição do leitor e os saberes em trânsito se modificam e modificam textos anteriores.
} 
Camargos Walty (Informação verbal), ${ }^{5}$ que, por sua vez, alarga a releitura de Rocha (2011). O movimento antropofágico vai além da visão de mundo que contempla a alteridade, da assimilação imediata ou do banquete presente na criação cultural; ele se dá no movimento recursivo da própria mente humana. Concebendo a metáfora como fenômeno de status cognitivo que, assim, permeia o modo como falamos, pensamos e agimos (Cf. LAKOFF; JOHNSON, 1980; FAUCONNIER; TURNER, 2002) e associando-a ao conceito de narratividade, capacidade humana de contar histórias (HUSTON, 2010), Walty vê as retomadas como processo da mente humana que, em incessante interação dialógica com os seres, com o mundo, em atividades perceptocognitivas, constrói sentido. No processo de significação, corpo e mente não são dissociáveis, ou seja, a compreensão emerge a partir da relação corpo-mente-linguagem-ação-pensamentomundo.

Percebamos, assim, que o que se destaca em todas essas reflexões - do Barroco revisitado, do estilo barroco presente no modo de conceber o mundo contemporâneo, do uso de dados culturais como materiais para criação (não só artística), da figura do antropófago humano em inúmeras e infinitas apropriações - é o movimento constitutivo na/da mente, capaz de sempre estabelecer relações. O movimento relacional vai ao encontro do que hoje é considerado patente entre os cognitivistas: a mente humana é inerentemente literária (TURNER, 1996). Os seres humanos são criativos a ponto de se projetarem em espaços e tempos diversos, usando sua aguçada capacidade de contar histórias, estabelecer relações, criar deslocamentos. Fazemos projeções a todo momento, encaixando cenas, ou seja, nossa mente é literária porque é recursiva.

5 Aula inaugural da turma 2020 do Programa de Pós-graduação em Letras/Estudos literários da Universidade de Montes Claros (Unimontes) proferida por Ivete Lara Camargos Walty, em 25 de agosto de 2020, intitulada Antropofagias e antropoemias: a pintura de Adriana Varejão. 
Por esse movimento recursivo também se pauta o escritor Autran Dourado na composição de sua obra Os sinos da agonia, ${ }^{6}$ em que há uma atualização de mitos clássicos (a trama de uma mulher que se apaixona pelo enteado e arquiteta a morte do marido) e um "retorno do barroco", em uma espécie de "reciclagem cultural", em que os elementos estruturam não só o conteúdo, mas seu estilo de escrita. Justifica o autor que o mundo é criado e (re)criado a partir de histórias contadas, pois “a capacidade de criar mitos, como a de sonhar, é inata ao homem [...]. É uma atividade do espírito, uma elaboração natural, que continuará sempre existindo [...] (DOURADO, 2005, p. 77). E ainda pontua: "O barroco para mim não é apenas um conceito histórico, capítulo da história da arte, mas alguma coisa viva e atuante [...]" (DOURADO, 2000, p. 38). Entendemos este algo vivo e atuante como um movimento que se atualiza de forma criativa e transgressora, longe do conceito de estilo de época, conjunto de condicionamentos que acabam por querer moldar e limitar o objeto artístico. Trata-se da criação de cenários altamente imagéticos em que as personagens e os leitores vivenciam experiências encenadas por meio dos sentidos.

Podemos apontar que, de fato, o barroco possui certo caráter sedutor, com sua tendência ao exagero, ao desvelamento

\footnotetext{
6 Em Os sinos da agonia, temos encenada a história de uma família de proprietários de terras nas Minas Gerais do século XVIII. João Diogo Galvão, um desbravador, bruto e sem sofisticação, casa-se com Malvina, delineada como linda e muito ambiciosa. Cria-se uma contraposição, em que Malvina vai exercendo todo seu poder de persuasão sobre o marido, sofisticando-o e enfraquecendo-o enquanto homem autoritário e patriarcal. Com o retorno de Gaspar, o filho de João Diogo, letrado e delicado que havia se embrenhado pelo sertão quando soube do casamento do pai com uma moça vinte anos mais jovem, cria-se um impasse. No entanto, Malvina consegue fazê-lo sentir-se à vontade, tecendo a teia que transformará essa súbita empatia entre madrasta e enteado numa paixão cheia de interditos. Em função do caráter íntegro de Gaspar, ela sabe que precisará livrar-se de João Diogo, pois o filho jamais trairia o pai. Torna-se, então, amante do mameluco Januário e o convence a matar o marido. Consumado o assassinato, Januário foge em companhia de Isidoro, seu escravo. É acusado, todavia, de algo mais grave: participar da conspiração contra o reino, conhecida como Inconfidência e, por isso, tem decretada sua morte em efígie. Assim, Malvina retira de seu caminho tanto Januário como João Diogo e revela seu amor ao enteado, que, no entanto, a afasta. Levada à loucura em função de sua paixão, Malvina se suicida ao perceber que o enteado não cederá aos seus encantos, mas antes escreve à polícia, acusando Gaspar e a si própria pela morte de João Diogo. Januário, inocentado pela carta de Malvina, é morto num confronto com a polícia, visto que já estava condenado e morto em efígie pelo poder de El-Rei. (Esse breve resumo transforma em reles relato cronológico uma narrativa não-linear e não dá a menor ideia da técnica narrativa engendrada pelo autor. Fica o convite à experiência profícua da leitura do romance.)
} 
e ao velamento por meio de imagens e palavras, no movimento em que todos os sentidos são postos em função da construção da significação das coisas do mundo. Autorizados somos a falar em um sentir barroco, um olhar barroco, um auscultar barroco que não estariam engessados em teorias estéticas e insertos em cronologias. O barroco, dado como modo de se ver e estar no mundo, se fundaria na relação com elementos de outras épocas e culturas, significando-os com base em determinado tempo e lugar. Essas reflexões nos permitem concebê-lo como metáfora estruturada/estruturante da mente corporificada humana, um movimento artístico vivo que dialogaria com o caótico mundo humano. E mais que isso: sendo a metáfora e a narratividade intrinsecamente ligadas à atividade de produção de sentidos pelo homem em seu nicho biofísico-social-cultural, ou seja, em suas vivências, concebemos o barroco como estilo de uma encenação da capacidade antropofágica da mente humana, ou seja, de sua capacidade ilustrativa e recursiva.

Na obra, a retomada de uma época passada (o Brasil colonial, a Vila Rica barroca, ilustrando seus procedimentos repressivos, sua crise econômico-financeira, abusos de poder existentes em diferentes instituições da sociedade, vozes de vencidos calados ou eliminados) ainda conduz nosso olhar também para a época em que foi escrita, 1974. Vale lembrar que o autor foi orientado a fazer uma nota para driblar os censores, em que se deixasse claro seu estrito diálogo com os mitos gregos e a construção de um romance ambientado no século XVIII. ${ }^{7}$ De fato, combinou

\footnotetext{
O período ditatorial no Brasil foi marcado por grande efervescência cultural, em que pese a existência de um departamento autoritário de censura oficial, destinado a proibir tudo o que fosse considerado subversivo. Isso foi mais rigoroso a partir da vigência do Ato Institucional $\mathrm{n}^{\circ} 5$, em dezembro de 1968, forma de dominação pela coerção, limitação ou eliminação de vozes discordantes do Estado. Por essa razão, muitos escritores usaram, como nunca, "estratégias linguísticas" marcadas por inversões, ironias, duplos sentidos, que passavam despercebidas pelo Departamento de Censura de Diversões Públicas (DCDP), e conseguiram driblar o crivo dos censores. A nota "fingida" no livro esteve presente nas duas primeiras edições e foi retirada com o abrandamento da censura. Para saber mais a respeito de obras censuradas pelo departamento, acessar o artigo da professora Sandra Reimão (2014).
} 
temas e motivos na tragédia clássica com a história política de Minas Gerais, de modo a ressignificar o passado e trazer, em sua composição, atrocidades e arbitrariedades que remetem ao violento período ditatorial pelo qual passava o Brasil. Mas, partindo do pressuposto de que a enunciação literária é uma espécie de mediação na relação do homem com o mundo, por meio do simbólico, e que, por isso mesmo, ela transcende o limite do tempo histórico, a obra nos permite refletir sobre a história brasileira, repleta de muitas crises e estilhaços, não apenas nos dois períodos citados. É um convite à reflexão crítica e, em um alargamento de sentido, como ela encena a experiência humana - como, aliás, a literatura faz -, possibilita o pensar a nossa própria condição em nosso tempo e, torna-se, assim, atemporal. Sempre um chamado a olhar o passado a partir do presente. É importante atentar que, nessa descrição temática, destacamos a atitude retroalimentativa de um autor que se vale de dados culturais para construção de um artefato criativo em que as fronteiras estão esfumadas e embaralhadas, marcando um lugar de importância para o leitor na percepção das apropriações, na construção dos sentidos que se dá na emergência das cenas enunciativas.

Em Leitura literária: enunciação e encenação, Graça Paulino e Ivete Walty (2005) salientaram a enunciação, o ato individual de apropriação da língua e sua transformação em discurso (BENVENISTE, 1989), como um operador capaz de possibilitar a leitura crítica do texto literário, considerando sua forma e sua inserção social. Tudo é ficção, dissimulação, mas isso não descola o texto do social. Mas, para se dar conta do desvelamento das relações sociais: 
[...] é essencial que o leitor se dê conta do jogo. Há um aqui e agora, há um ontem, um hoje e um amanhã, há um sujeito enunciador, há um leitor; tudo isso se desdobrando infinitamente, relativizado em cada performance do texto e da leitura. Tal desdobramento pode evidenciar o caráter intertextual, muitas vezes metalinguístico, mas sempre mutável, sempre histórico. (PAULINO; WALTY, 2005, p. 143).

Trata-se de uma cadeia enunciativa representada: linguagem assumidamente encenada, multiplicidade de enunciadores, profusão de vozes e retomadas/apropriações. O "Jogo e construção, o aspecto lúdico da montagem, a múltipla leitura que o barroco propõe [...]" (DOURADO, 2000) encantaram o autor que faz a narrativa dobrar-se sobre si mesma. De modo fractal, em que a parte é formada do todo e o todo está contemplado na parte, uma mesma história tem enquadramentos distintos e se repete sob perspectivas diferentes, distribuída por quatro blocos. Esses blocos narrativos parecem soltos e independentes, mas mantêm relações interiores, (des)velando tensões e conflitos entre personagens e cenários. Cada jornada, como é chamada cada parte do texto, repete a mesma trama, que nunca é igual: repetição e diferença. $\mathrm{O}$ artesão Dourado (alcunha do escritor) molda sua obra de maneira consciente, rompendo com a estrutura clássica do romance, privilegiando a heterogeneidade de vozes e a experiência da alteridade como artifício dessacralizador da tradição literária romanesca.

Dessacralização que se propaga pelas cenas. Pinçada entre muitas, temos em destaque a pintura do teto da sala principal da casa da Rua Direita, lugar que abriga Malvina e Diogo Galvão após o casamento, um rico sobrado erguido no centro do poder e, não por acaso, perto das principais igrejas e do palácio do Capitãogeneral. A pintura rasura o ambiente ricamente ornamentado. 
O espaço das artes, onde acontecem as festas e os saraus, com lustre de cristal, tapetes, grandes cortinados, cadeiras de madeira entalhada, canapé com assento forrado de damasco, consolos e mesas filetadas, pinturas e um cravo "todo pintado a ouro, com medalhões, conchas, liras e figuras mitológicas", instrumento típico da música barroca e símbolo de requinte e refinamento, aponta para o excesso e o derramamento, à moda dos espetáculos que acontecem no espaço público (a morte em efígie, a procissão de Corpus Christi, festa do Triunfo Eucarístico), jogo especular da narrativa, modo barroco de escrita.

Pintura de alto preço, mesmo um pintor de alegorias foram arranjar. Nos painéis do teto as quatro estações, junto do lustre de flores e guirlandas, cupidos e medalhões. Pintura de cores vivas e chapadas, azul e vermelho, verde carregado, o preto com que se acentuava o risco das figuras. Sorriu diante dos cupidos, pareciam mais dois anjinhos de igreja, as feições brejeiras. Uma pintura singela e imperfeita, uma figuração que fugia dos cânones, uma mistura de oriente e ocidente, de fábula grega e frutos da terra, pensou o mazombo desenraizado que ele não conseguia deixar de ser. A vista acostumada aos riscos e contornos suaves e esbatidos, às nuanças e róseos entretons das encarnaduras, aos meio tons, à passagem das cores para as sombras nos panejamentos, à perfeição das figuras, à pintura agora em moda nos lugares por onde andou, sorria condescendente diante do pintor anônimo que não tinha a arte de outros reinos, que não conhecia os lugares que ele conheceu. Mazombo da Ilustração, estranhava as cores quentes demais, lisas. E as letras das cartelas, floreadas e desproporcionais. Certamente o pintor não sabia ler, senão não separaria as letras assim. (DOURADO, 1991, p. 152)

Os painéis das quatro estações descritos pelo olhar de Gaspar destoam da ordenação de todo o ambiente. $\mathrm{O}$ filho que retornara da Europa e que comporia o triângulo amoroso com o pai delineia 
o embate entre dois projetos artísticos: o neoclassicismo, com suas formas simétricas e racionais, e o barroco, que traz em seu bojo o conflito entre o racional e o irracional, o esfumaçamento dos contornos, a liberação formal. Não há, no Barroco, comedimento, mas êxtase e ebriedade. O estilo não procura a plenitude do ser comedido, mas as tensões arrebatadoras de um estado apaixonado de existência. A sala acolhe, em vários momentos, madrasta e enteado, dois seres contraditórios, e seus adornos e pinturas metaforizam a angústia entre o controle e o extravasamento. As cores também os acolhem: ele, calmo, casto e frio como o azul; ela, energizante, apaixonada e calorosa como o vermelho. Pureza e malícia contrapostas e mescladas no mesmo espaço, personagens díspares aproximadas.

Figuras da tragédia grega se misturam a elementos nacionais e, pelo olhar do "mazombo desenraizado", que estudou no estrangeiro, vemos encenada a desvalorização da arte nacional. Feito por um "pintor de alegorias", que podemos tomar como metáfora do autor, o cenário descentra e desterritorializa a pintura europeia e, seguindo o olhar da personagem, somos convidados a perscrutar as imagens. A junção de elementos díspares que encenam os movimentos artísticos nos direciona para a escrita ambígua da narrativa a promover o encontro de contrários. A mistura de elementos clássicos com elementos da terra também nos remete à antropofagia barroca de Haroldo de Campos (2006). O "devorar" do legado cultural do estrangeiro é um estado de ruptura e, ao mesmo tempo, de criação, que pressupõe a relação com a alteridade. Não há negação da influência, mas assunção da importância do outro para nossa constituição, um procedimento antropológico, como bem colocado por Castro Rocha (2011). Há o acolhimento, pela escrita, dos dois pontos de vista díspares: o 
de Malvina, que encomenda a pintura e que valoriza o diálogo entre as artes, e o de Gaspar, que enaltece os parâmetros europeus em detrimento da arte brasileira.

A estrutura da narrativa também sugere, pelo desenho periódico das estações, começo e fim, vida e morte, presente nas quatro jornadas da obra: repetição, recorrência, ritmo da narrativa e da vida humana. A aproximação entre natureza e homem é ilustrada por meio do fenômeno que os une: o ciclo. Definidas de acordo com o movimento orbital da Terra em relação ao Sol, as estações se sucedem, em eterno retorno, que nunca é o mesmo, sempre renovado. Da mesma forma, a vida humana vai do nascimento à morte e recomeça com novo nascimento. $\mathrm{Na}$ mesma direção, a escrita: nascimento, criação, fim e recomeço; a cada nova leitura, nova atualização, novo processo. Infinidade de mitos e histórias, constantemente retomados e ressignificados.

Avançando com as considerações de Ivete Camargos Walty, ${ }^{8}$ visualizamos a mente recursiva e antropofágica do autor mineiro, propondo deslocamentos na montagem fragmentária de um novo texto, tematizando o conflito e o desajuste. Uma bricolagem de fragmentos encontrada também nos espetáculos dos espaços públicos citadinos, jogo metonímico da obra. Eventos profanos e sagrados se misturam e se realizam a céu aberto, a olhos vistos. Como bem nos lembra o crítico Otto Maria Carpeaux (2008, p. 649), "[a] índole da literatura barroca é dramática, ou melhor: teatral. No centro da civilização barroca está o teatro [...]". Por extensão, diríamos que o modo barroco de ver/perceber o mundo e a estruturação barroca de narrativa também são teatrais, mesmo porque é teatral o modo de se vivenciar o mundo. Dourado traz para sua obra a temática da vida como representação e sua 
expressão alegórica. $\mathrm{Na}$ espetacularização do mundo, o código visual era a forma de expressão predominante no Barroco, e é sem dúvida a forma de expressão predominante em nossa época, uma verdadeira civilização da imagem.

Mais importante que perceber as representações teatrais feitas no palco da cidade - com suas sinuosas ladeiras e estreitas ruas que, a um só tempo, captam os sentidos do leitor, velam e desvelam agonia, dor, sofrimento, mazelas políticas, relações de poder, embustes e que nos remetem às características barrocas e ao modo de ver/perceber o mundo -, é atentar para sua construção compósita. A morte em efígie remonta, em um primeiro momento, ao período medieval da Inquisição em que a Igreja Católica, aliada ao poder político, combatia com extrema violência atitudes consideradas "desviantes" e, na falta da apreensão do indivíduo, castigava o simulacro. $\mathrm{O}$ ritual nos leva ainda aos princípios da magia em que o efeito se assemelha à causa, em que coisas/objetos/seres estão em interrelação, mesmo quando afastados no espaço, por similaridade ou lei de contágio. A retomada mais visível, no entanto, se dá com descrições retiradas de documentos históricos, num jogo intertextual referenciado nas epígrafes do romance, ${ }^{9}$ e que nos leva ao século XVIII, escancarando a violência simbólica do poder soberano sobre seus súditos. A vítima, representada na efígie, é sua cristalização numa imagem retroprojetada: termina o homem e começa o modelo, o paradigma. Trata-se de uma variante da morte civil em que o arremedo ganha ares de verdade. Exposto à violência física por qualquer membro da comunidade,

\footnotetext{
9 Das quatro epígrafes que abrem o romance, três são relatos históricos: Capítulos de História Colonial, de J. Capistrano de Abreu, História Antiga das Minas Gerais, de Diogo de Vasconcelos, Vida e morte do bandeirante, de Alcântara Machado,e buscam definir "a morte em efígie", medida violenta de repressão utilizada em tempos coloniais, saturados de arbitrariedades e suplícios. A quarta epígrafe foi retirada do Diccionario da Lingua Portugueza, cuja segunda edição data de 1789, e define o que significa "relaxar" em carne. De certa forma, os fragmentos desses documentos antecipam e encenam o tom fúnebre que atravessará toda a narrativa, uma vez que as personagens encenadas têm a existência aniquilada pela morte.
} 
o corpo está morto socialmente. A inscrição da História na ficção, mais que indiciar o procedimento comum no Brasil colonial, dessacraliza-a e coloca em xeque a oposição entre verdade e ficção, real e imaginário, história oficial e testemunho. Embaralhamento de fronteiras.

O espetáculo com brilho e pompa encenado no romance beira o desequilíbrio e o desregramento, reconhecidos pelo público: "Quando passava a carreta, todos recolhiam o riso, emudeciam. Mesmo interiormente reparando, ninguém tinha a coragem de falar que o Capitão-General levava longe demais a sua fantasia." (DOURADO, 1991, p. 29). O cenário, mais uma vez, vai sendo construído por meio de misturas e contraposições, valendo a pena a descrição: na rua, "gente sem eira nem beira", pretas "vestidas de panos e xales berrantes", "arraia miúda e desrespeitosa"; no espaço privado, na sacada dos sobrados, "gente de casta ou fumaça", mulheres "ruivas, rubras, alvaiadas, espaventosas" com "vestidos decotados, de veludo ou tafetá bordados a ouro, cobertas de aljôfares, pérolas", homens "nas suas melhores véstias". Além disso, ouviam-se "gracejos e informações", mas também "cabeludos palavrões"; a festa é uma farsa, que o Capitão quer real; o povo aguardava desde a véspera a "soturna solenidade", mas também o "alegre divertimento que todos esperavam quando o terror do mando real os abandonava por alguns momentos". "Na manhã bem cedinho" reverbera a tensão: "a cidade engalanada e festiva como se fosse um dia de soberba alegria e não de macabra ópera e condenação [...]" (DOURADO, 1991, p. 25). A rua metaforiza a ambiguidade barroca, não só pelas características de sua estrutura física, mas por ser também um amálgama de gente e objetos, uma expressão da tensão dos contrários. $\mathrm{O}$ espaço público da cidade 
é apresentado, paradoxalmente, como lugar de multiplicidades, de controle e opressão, de conflitos e embates.

De vez em quando passavam em disparada soldados de espada desembainhada e os mais alegres se afastavam ruidosos, gritando vivas a el-Rei e ao Capitão-General, de puro medo das patas dos cavalos, dos ferros dos sabres e espadas. Trocavam-se gracejos e informações, diziam-se os mais cabeludos palavrões. Era uma festa de moleques e mucamas em dias de folga, do femeaço e dos feitores, de pretos forros e brancos pobres, de mulatos e mamelucos, cafuzos, entrecruzas de caburés e curibocas, carijós. Aquele caldo de gente quente e espumante de onde nasciam as flores gálicas e os esquentamentos. Um grande festim de raças e ofícios, selvagem, infernal, puro trópico.

Os moradores dos sobrados da Rua Direita e da praça, gente de casta ou fumaça, trouxeram seus tamboretes para junto das janelas e sacadas enfeitadas, cobertas de brocados e damascos, de colchas de seda franjadas, e se divertiam vendo aquele poviléu de gente sem eira nem beira... os homens bons e os fidalgos muito antigos nos livros del-Rei, como gostavam de pavonear, mentirosamente ou não, eram mais receosos e só chegariam à frente quando o Capitão-General aparecesse na sacada principal do palácio ou descesse à praça, não se sabia, para que fossem vistos e nem de longe fosse posta em dúvida a sua lealdade à Sua Fidelíssima Majestade em Lisboa. (DOURADO, 1991, p. 27).

Notemos que, nesse excerto, a enumeração excessiva se reveste de conotações semânticas ajustáveis à dimensão barroca da obra. Nosso olhar é remetido às minúcias, aos pormenores que particularizam o cenário, construído de variedade e multiplicidade. Há exagero de ruídos, cores e gentes, mistura de texturas, tecidos e brocados, em um jorro de imagens que apontam sempre para a abundância e o extravasamento. 
Além disso, o descomedimento da enumeração impõe ritmo, mobilidade e rapidez à cena. Por outro lado, as ruas apresentamse como espaço organizado, sistematizado, à medida que, longe de favorecer a diluição das diferenças e papéis dados cultural e socialmente, registram-nos e reafirmam-nos.

Outra estratégia narrativa importante na obra é o constante encaixe de cenas. Os acontecimentos ocasionados pelo evento do enforcamento em efígie, por exemplo, são reconstruídos pela memória imaginativa da personagem Januário a partir dos relatos de seu escravo, Isidoro. Para o condenado, o cortejo se parecia demais com a procissão do Triunfo Eucarístico, encenação sobreposta à cena relatada pelo escravo e que também se apresenta como jogo especular do ritual fúnebre. O desajuste é total: o "festim" tem ares carnavalescos, bem ao modo dos trópicos, em uma ambientação de sacrifício e religiosidade. $\mathrm{O}$ evento católico desvela um poder religioso que se associa ao poder político e econômico de modo a reger os valores ditados à sociedade. Nada mais orgiástico que esse evento em que a razão parece estar suspensa. Nada mais barroco e contemporâneo.

A escuta de Januário sobre sua morte em praça pública traz à memória outras cenas sobre as quais já tinha ouvido ou com as quais já tinha sonhado, cenas a respeito de sacrifícios e sortilégios, enforcamentos, sofrimentos e agonia, em uma verdadeira sobreposição de figurações: encaixes no presente da enunciação. Em sua rememoração, são trazidas as vozes dos condenados "pretos açoitados entre lágrimas, uivos, sangue, mijo e suor, no pelourinho" (DOURADO, 1991, p. 31) e dos presos a grilhões, com vozes que, como a dele, não são ouvidas nem pelas instituições políticas nem pela instituição religiosa, a não ser pela promessa de ocupar um céu inventado pelos 
brancos. São trazidas à cena as figuras hierárquicas da Igreja e da Justiça: juízes, camaristas, soldados, alferes, capitães, coronéis, padres, monsenhores, cônegos e bispos, que não protegem ou acolhem essas vozes. $\mathrm{O}$ acolhimento acontece pela escrita que as encena de maneira perturbadora na medida em que embaralha tempos, espaços, histórias sofridas e/ou sonhadas. Há de se ressaltar que essa estruturação da escrita propicia a todo momento interpenetrações entre presente, passado e futuro, projeções densas, antecipações, inclusive pelas encenações oníricas, "sonhos atropelados, uns saindo de dentro dos outros, como muitas caixas vazias." (DOURADO, 1991, p. 47).

A celebração do Corpus Christi, festa católica em que se comemora a salvação do pecado do mundo pelo sacrifício do filho de Deus, mais pomposa e sofisticada, nos remete à morte de uma vítima inocente, assim como a personagem morta em efígie. A violência estrutural do mecanismo sacrificial funda nossa sociedade: sistemas religiosos, ritos, proibições, sistema judiciário (GIRARD, 2008). “As mesmas gentes e irmandades, só que no cortejo do enforcamento não havia santos e andores, carros triunfais e figuras de Ventos e Planetas, a não ser os padres e o cruciferário." (DOURADO, 1991, p. 51). Sim, o cruciferário está em destaque nas duas procissões a nos lembrar que, assim como a personagem delineada no romance, Cristo também foi uma vítima sacrificável, um bode expiatório a purgar os pecados da comunidade por meio de seu sacrifício. As duas figuras seriam, no romance, espelhadas. No entanto, Cristo, ao se entregar para o sacrifício, rompe com a violência sacrificial arcaica e ensina o amor e o perdão como verdadeiros caminhos para a humanidade. "Cristo deseja que os homens reconheçam o papel dos fazedores de vítimas, de perseguidores. É porque 
proclama as regras do reino e renuncia totalmente à violência sacrificial que o próprio Cristo é sacrificado [...]" (GIRARD, 2009, p. 9). Dessa forma, esse espelhamento da personagem na figura de Cristo, cuja paixão está sendo encenada nas ruas, rasura, de maneira bastante crítica, a instituição católica que, aliada ao poder político, participa de outro ritual sacrificial, perpetuando a violência.

O desdobramento de tempos e espaços se encena. Nas lembranças da procissão do Corpo de Cristo, é significativo o trecho em que Mulungu, responsável pelos golpes na efígie, é inserido novamente no cenário das sinuosas rememorações de Januário. O carrasco, no entanto, faz parte do cenário da fingida execução, que ainda virá a acontecer na narrativa. Poderíamos dizer que a manifestação de uma memória passada acaba por conduzir uma manifestação futura, a memória do futuro, ocasionando uma certa confusão mental da personagem:

\begin{abstract}
Agora seguia de longe a procissão, os olhos maravilhados. O cruciferário erguendo alto o Cristo de prata, todos se ajoelhavam se benzendo à sua passagem. Mulungu, o peito, nu, brilhoso. O que estava fazendo ali o preto Mulungu? Não, não era sonho, ele sabia, apesar da nitidez diáfana, do brilho das coisas. Procurava atribuir a presença de Mulungu à cabeça cansada, à sua confusão de espírito. (DOURADO, 1991, p. 51-52).
\end{abstract}

Há a instauração de uma cena enunciativa, explicitada pelo uso do advérbio "agora", e, a partir desse enquadramento, outras cenas são criadas, relacionadas e, simultaneamente, reveladas. Estamos mais uma vez nos referindo às projeções de tempos e espaços que mimetizam o que de fato acontece na mente humana. Toda essa capacidade recursiva parece sintetizada no seguinte excerto da obra: 
Assim como havia em Malvina uma memória do futuro e em Gaspar uma memória do passado, pode-se dizer que havia para ele um destino do passado e para ela um destino do futuro. Embora, essas palavras, assim juntas, sobretudo memória do futuro e destino do passado, possam parecer contraditórias e arbitrárias, e na verdade o são e os seus conceitos e significados se chocam e se contradizem (comumente a memória diz respeito ao passado e às coisas ausentes mas vivas, ou melhor - mortas, porque acontecidas, a matéria do destino é sempre o futuro e as coisas latentes, lívidas, ainda por acontecer), só recorrendo a uma arbitrária e contraditória aproximação, a um símile ou metáfora, poderemos entender e amar dois seres tão diferentes e tão próximos, de encontro difícil, senão impossível, a não ser pela destruição, e tudo que com eles se passou e ainda passará. (DOURADO, 1991, p. 146).

A capacidade narrativa do ser humano, capaz de superar o "aqui" e o "agora" do presente para criar um "lá" e "depois" virtuais, se vê manifestada de modo elaborado nos textos ditos literários. No romance aqui analisado, Autran Dourado constrói suas personagens se projetando a todo momento em um futuro sonhado e desejado, ou acessando acontecimentos não contemporâneos ao momento em que se enunciam, de modo a encontrar saídas e explicações para o que lhes acontece. Deparamo-nos com os pensamentos das personagens, que experienciam tempos não presentes: passados ou futuros. Ainda assistimos a eles em espacializações em que mergulham em delírios e devaneios, criando histórias e se projetando nelas, tal qual, reiteramos, a capacidade narrativa humana.

As características do gênero em questão e o aspecto disciplinador do prazo sempre nos obrigam a colocar fim ao que poderia se estender à exaustão.Algunspontos, acreditamos, devem ser reiterados. A contemporaneidade mostra-se polissêmica, no 
sentido de acolher sempre ideias e imagens que nunca são, de fato, novas, mas, sim, retomadas de dados culturais. A sintaxe contemporânea embaralha fragmentos de produções existentes, num movimento incessante de apropriação. Podemos pensar em obras compósitas cuja sensibilidade imagética nos leva à produção de sentidos, sempre corpórea. Nossa época fissurada, marcada pelo estranhamento e pela complexidade, aproximase do barroco, em seu caráter descontínuo e assimétrico. Os sinos da agonia, obra barrocamente construída, ilustra essa aproximação, já que o tom é caótico, dispersivo, fragmentado, em um indefinido jogo de entrecruzamento de vozes. Mais do que atentar para o estilo barroco de escrita de Dourado, e, por que não, de concepção de mundo, que apela para os sentidos e a experiência humana, imbricados no jogo metafórico, destacamos a obra como fruto da mente antropofágica do autor (ao integrar movimento artístico e modernidade, mitos clássicos e história colonial, elementos da tragédia e frutos da terra, eventos sacros e profanos) e como a própria encenação da capacidade devoradora da mente humana (ao promover encaixes de cenas, sobreposições de figurações, embaralhamento de tempos, espaços e histórias, jogo de projeções e antecipações). Uma capacidade ilustrada também neste trabalho: recortes e colagens de textos, não só escritos, que são também ecos de outras produções e que nos ajudam a ler a obra, ela mesma uma junção de retomadas de cenas míticas, de documentos históricos, de releitura da tradição, não deixando de ser inusitada e instigante. Ações integradoras que são, na verdade, fruto das ações integradoras da mente humana, antropofágica por natureza. Trata-se do movimento ininterrupto da criação do homem, em um trabalho recursivo da mente, feito no empenho de produzir sentidos para viver. 
A literatura tem o privilégio de ser incerta, duvidosa, infinita. Como nos aponta a epígrafe de Northrop Frye, ela engole a vida, o mesmo gesto antropofágico de que se vale a imaginação humana. A narrativa de Os sinos da agonia é construída dialógica, plurissignificativa e multiperspectivada, o que reserva a nós, leitores, o direito à incerteza dos sentidos. A obra continua aberta, a nos esperar para novas leituras e novas construções de sentido. A leitura que aqui se apresenta, na verdade, uma reescritura em que nosso traço é sobreposto a traçados outros, é apenas uma entre várias possíveis e é resultado da deglutição de um banquete proporcionado pelo antropófago Autran Dourado. Servidos?

\section{Referências}

ALVES, Roberta Maria Ferreira. Antropofagia em acordes dissonantes: uma possível digestão de um antropófago indigesto, Cadernos Cespuc, Belo Horizonte, n. 36, 1. sem. de 2020.

ANDRADE, Oswald. A utopia antropofágia. São Paulo: Globo, 1990.

BENJAMIN, Walter. Origem do drama barroco alemão. Tradução de Sergio Paulo Rouanet. São Paulo: Brasiliense, 1984. BENVENISTE, Émile. Problemas de Lingüística Geral II. Tradução de Eduardo Guimarães et al. Campinas, São Paulo: Pontes, 1989.

BORGES, Jorge Luis. Ficções. 6. ed. Tradução de Carlos Nejar. São Paulo: Globo, 1995.

CAMPOS, Haroldo. Da razão antropofágica: diálogo e diferença na cultura brasileira. In: Metalinguagem \& outras metas: ensaios de teoria e crítica literária. São Paulo: Perspectiva, 2006. p. 231-257. 
CARPEAUX, Otto Maria. História da literatura ocidental: volume II. 3. ed. Brasília: Edições do Senado Federal, v. 107-B, 2008.

DOURADO, Autran. O meu mestre imaginário. Rio de Janeiro: Rocco, 2005.

DOURADO, Autran. Os Sinos da Agonia. 7. ed. Rio de Janeiro: Francisco Alves, 1991.

DOURADO, Autran. Os Sinos da Agonia, romance pós-moderno. Revista USP, [S. l.]. n. 20, p. 119-124, 1994. Disponível em: http://www.revistas.usp.br/revusp/article/view/26908/28688. Acesso em: 28 dez. 2017.

DOURADO, Autran. Uma poética de Romance. São Paulo: Perspectiva, 1973.

DOURADO, Autran. Uma poética de Romance: Matéria de Carpintaria. Rio de Janeiro: Rocco, 2000.

FAUCONNIER, G.; TURNER, M. The way we think conceptual blending and the mind's hidden complexities. New York, Basic Books, 2002.

FRYE, Northrop. A imaginação educada. Tradução de Adriel Teixeira, Bruno Geraidine e Cristiano Gomes. Campinas: Vide Editorial, 2017.

GIRARD, René. A violência e o sagrado. Tradução de Martha Conceição Gambini. 3.ed. São Paulo: Paz e Terra, 2008.

GIRARD, René. O bode expiatório e Deus. Tradução de Márcio Meruje. Covilhã, 2009. Disponível em : http://www.lusosofia. net/textos/girard_rene_o_bode_expiatorio_e_deus.pdf Acesso em 22/07/2019.

GUERRA, Maria José Oliveira Araújo. A construção dos sujeitos nos cenários teatrais de Os sinos da agonia, de Autran Dourado. Dissertação (Mestrado)- Programa de Pós-Graduação em Letras, Pontifícia Universidade 
Católica de Minas Gerais, Belo Horizonte, 2019. Disponível em: $\quad$ http://www.biblioteca.pucminas.br/teses/Letras MariaJoseOliveiraAraujoGuerra_7992.pdf

HATZFELD, Helmut. Estudos sobre o barroco. São Paulo: Perspectiva, 2002.

HUSTON, Nancy. A espécie fabuladora. Tradução de Ilana Heineberg. Porto Alegre: L\&PM Editores, 2010.

KLUCINSKAS, J.; MOSER, W. A estética à prova da reciclagem cultural. Scripta, v. 11, n. 20, p. 17-42, 2017. Disponível em; http://periodicos.pucminas.br/index.php/scripta/article/ view/14019/11018. Acesso em: 02 jan. 2021.

LAKOFF, George; JOHNSON, Mark. Metaphors We Live. Chicago: University of Chicago Press, 1980.

MOSER, Walter. Versões do barroco: moderno, pós-moderno. Sociedade e Estado, v. VIII, n. 1/2, 1994.

PAULINO, Graça; WALTY, Ivete. Leitura literária: enunciação e encenação. In: MARI, Hugo; WALTY, Ivete; VERSIANI, Zélia (org.). Ensaios sobre leitura 1. Belo Horizonte: Editora PUC Minas, 2005. p. 138-154.

REIMÃO, Sandra. "Proíbo a publicação e circulação..." censura a livros na ditadura militar. Estudos avançados, São Paulo, v. 28, n. 80, 2014.

ROCHA, João Cezar de Castro. Uma teoria de exportação? Ou: "Antropofagia como visão do mundo". In: ROCHA, João Cezar de Castro; RUFFINELLI, Jorge (org.). Antropofagia hoje? Oswald de Andrade em cena. São Paulo: Realizações Editora, 2011. p. 647-668.

RUSSO, Vincenzo. Uma Dobra (Neo)Barroca: Modernidade, Pós-Modernidade e a inversão ideológica do Barroco, Gragoatá, Niterói, n. 27, p.51-80, 2. sem. 2009. Disponível em: https:// periodicos.uff.br/gragoata/article/view/33106/19093. Acesso em 02 jan. 2021. 
TURNER, M. The Literacy mind: the origins of thought and language. Nova York: Oxford University Press, 1996.

WÖLFFLIN, Heinrich. Conceitos fundamentais de história da arte. Tradução de João Azenha Júnior. São Paulo: Martins Fontes, 1984. 